\title{
Potential Role of Antipsychotic-Galantamine- Memantine Combination in the Treatment of Positive, Cognitive, and Negative Symptoms of Schizophrenia
}

\author{
Maju Mathew Koola \\ Department of Psychiatry and Behavioral Sciences, George Washington University School of Medicine and \\ Health Sciences, Washington, DC, USA
}

\section{Keywords \\ Schizophrenia - Cognition - Negative symptoms . Galantamine - Memantine - Randomized controlled trials . Efficacy signal · Methodological issues $\cdot$ Kynurenine}

\begin{abstract}
Schizophrenia is, in part, a cognitive illness. There are no approved medications for cognitive impairments associated with schizophrenia (CIAS) and primary negative symptoms. Cholinergic and glutamatergic systems, alpha-7 nicotinic acetylcholine (a-7nACh) and $\mathrm{N}$-methyl-D-aspartate (NMDA) receptors, kynurenic acid (KYNA), and mismatch negativity have been implicated in the pathophysiology of CIAS and negative symptoms. Galantamine is an acetylcholinesterase inhibitor that is also a positive allosteric modulator at the a $4 \beta 2$ and $\alpha 7 n A C h$ receptors. Memantine is a noncompetitive NMDA receptor antagonist. Galantamine and memantine alone and in combination were effective for cognition in animals and people with Alzheimer's disease. The objective of this article is to critically dissect the published randomized controlled trials with galantamine and memantine for CIAS to highlight the efficacy signal. These studies may have failed to detect a clinically meaningful efficacy signal due to limitations, methodological issues, and possible medication non-
\end{abstract}

adherence. There is evidence from a small open-label study that the galantamine-memantine combination may be effective for CIAS with kynurenine pathway metabolites as biomarkers to detect the severity of cognitive impairments. Given that there are no available treatments for cognitive impairments and primary negative symptoms in schizophrenia, testing of this "five-pronged strategy" (quintuple hypotheses: dopamine, nicotinic-cholinergic, glutamatergic/NMDA, GABA, and KYNA) is a "low-risk high-gain" approach that could be a major breakthrough in the field. The galantaminememantine combination has the potential to treat positive, cognitive, and negative symptoms, and targeting the quintuple hypotheses concurrently may lead to a major scientific advancement - from antipsychotic treatment to antischizophrenia treatment.

(c) 2018 S. Karger AG, Basel

This material was presented at the 72nd Society of Biological Psychiatry Annual Scientific Convention, May 18-20, 2017, San Diego, CA, USA; at the 56th American College of Neuropsychopharmacology meeting, December 3-7, 2017, Palm Springs, CA, USA; at the 73rd Society of Biological Psychiatry Annual Scientific Convention, May 10-12, 2018, New York, NY, USA; at the American Society of Clinical Psychopharmacology meeting, May 29 to June 1, 2018, Miami Beach, FL, USA; and at the 57th American College of Neuropsychopharmacology meeting, December 9-13, 2018, Hollywood, FL, USA

\section{KARGER}

(c) 2018 S. Karger AG, Basel

E-Mail karger@karger.com

www.karger.com $/ \mathrm{mnp}$
Maju Mathew Koola, MD

Department of Psychiatry and Behavioral Sciences

George Washington University School of Medicine and Health Sciences

2300 I St NW, Washington, DC 20037 (USA)

E-Mail majumkoola@gmail.com; mkoola@ gwu.edu 


\section{Introduction}

Schizophrenia is, in part, a cognitive illness [1]. Cognitive impairments associated with schizophrenia (CIAS) are core features of schizophrenia. CIAS is the best predictor of functional outcome [2]. Unfortunately, there are no approved medications for CIAS. Cholinergic $[3,4]$ and glutamatergic systems $[5,6]$, alpha-7 nicotinic acetylcholine ( $\alpha 7 \mathrm{nACh})$ receptors [7], and $N$-methyl-D-aspartate (NMDA) receptors [8] have been strongly implicated in the pathophysiology of CIAS. The Measurement and Treatment Research to Improve Cognition in Schizophrenia (MATRICS) project, designed to facilitate the development of new drugs for the treatment of cognitive impairments in people with schizophrenia, identified three drug mechanisms of particular interest: dopaminergic, nicotinic-cholinergic, and glutamatergic [9].

Galantamine is an acetylcholinesterase inhibitor that also acts as an allosteric modulator at the $\alpha 4 \beta 2$ and $\alpha 7 \mathrm{nACh}$ receptors [10]. Memantine is a noncompetitive NMDA receptor antagonist [11] that attenuates the neurotoxic tonic overstimulation of NMDA receptors by glutamate [12]. Through the presynaptic a $\mathrm{nACh}$ receptor, galantamine increases glutamate release [13-15]. The synergistic actions of the $\alpha 7 \mathrm{nACh}$ and NMDA receptors and cholinergic and glutamatergic systems were demonstrated in pyramidal neurons of the auditory cortex in rats. The authors argued that this synergistic action led to synaptic plasticity in the sensory neocortex [13]. Memantine decreases the tonic NMDA current, and galantamine enhances the action potential mediated by a postsynaptic NMDA current, which results in an increased signal transmission $[16,17]$. Therefore, a greater signal-to-noise ratio occurs with the galantamine-memantine combination than with memantine alone $[16,17]$. Galantamine improves the a-amino-3-hydroxy-5-methyl-4-isoxazolpropionate (AMPA)-mediated signaling, which could be neuroprotective and may improve memory coding [16, 17]. The synergistic action of NMDA and AMPA receptors is well documented [18]. Galantamine may augment the noise suppression of memantine's glutamatergic action. Galantamine potentiates glutamatergic neurotransmission mediated by AMPA and NMDA receptors [19]. Memantine modulates Kir6.2 activity (Kir6.2 is a major subunit of the ATP-sensitive $\mathrm{K}^{+}$channels and functions in synaptic plasticity). It has been argued that the Kir6.2 channel is a novel therapeutic target to enhance cognition in people with Alzheimer's disease (AD) [20]. This mechanism of action may be relevant in schizophrenia as well. Galantamine [21] and memantine [22,23] have increased

Antipsychotic-Galantamine-Memantine Combination for Schizophrenia Treatment brain-derived neurotrophic factor (BDNF). Finally, galantamine [24-26] and memantine [27] have antioxidant activity.

The $\alpha 7 \mathrm{nACh}$ receptor enhanced NMDA cognitive circuits in the dorsolateral prefrontal cortex (dlPFC) in monkeys. $\alpha 7 \mathrm{nACh}$ receptor stimulation is essential for the excitation of NMDA receptor-mediated attention and working memory circuits [28]. Stimulation of the nicotinic $\alpha 4 \beta 2$ receptor enhanced attention and working memory-related firing of dlPFC in monkeys [29]. The combination of galantamine and memantine improved the attentional set-shifting task and novel object recognition task in rodents compared to vehicle-treated rats; the combination was more effective than either medication alone because of the synergistic role of the $\alpha 7 \mathrm{nACh}$ and NMDA receptors [30]. In older rabbits, the galantaminememantine combination had a superior effect on cognition compared to the donepezil-memantine combination [31]; memantine was common in both combinations, thus this finding suggests a synergistic role of the $\alpha 7 \mathrm{nACh}$ and NMDA receptors. The galantamine-memantine combination produced synergistic neuroprotection in a transient global cerebral ischemia model in gerbils [32]. Several other preclinical studies have shown that cognition was significantly $[33,34]$ and synergistically $[35,36]$ improved with the galantamine-memantine combination than with either medication alone.

In a 2-year randomized controlled trial (RCT) with 232 elderly subjects with cognitive impairments, in AD prodrome $(n=39)$ a combination of galantamine and memantine significantly improved cognitive scores compared to galantamine alone; cognitive decline occurred after discontinuation of galantamine [37]. In $\mathrm{AD}$ patients, the galantamine-memantine combination $(n=53)$ significantly improved cognition compared to donepezil-memantine $(n=61)$ [38]. Given the overlap in pathophysiology, these findings in animals and in patients with $\mathrm{AD}$ may be translated to patients with schizophrenia [39, 40].

In a meta-analysis of 6 RCTs in schizophrenia $(n=$ 226), galantamine significantly improved cognition (effect size $=0.233 ; p<0.001)$ compared to placebo [41]. In a meta-analysis of 8 RCTs in schizophrenia $(n=$ 448), memantine improved cognition (mean difference $[\mathrm{MD}]=3.07, p<0.0001$ ), negative symptoms (standardized MD $[\mathrm{SMD}]=0.96, p=0.006)$, and psychosis $(\mathrm{SMD}=$ $0.46, p=0.07)$ compared to placebo [42]. In another metaanalysis of 8 RCTs $(n=452)$ in schizophrenia, memantine improved cognition compared to placebo, with a weighted MD of $3.09(p<0.00001)$ [43]. Improvements in negative symptoms, which are associated with functioning $[44,45]$, 
have also been shown with memantine. However, these findings should be taken with caution, as negative symptoms were measured with the Scale for the Assessment of Negative Symptoms (SANS), the Positive and Negative Syndrome Scale (PANSS), and the Brief Psychiatric Rating Scale (BPRS), which do not differentiate primary versus secondary negative symptoms, instead of the Schedule for the Deficit Syndrome [46], which does differentiate these symptoms.

The objective of this article is to critically dissect [47, 48] all of the published studies conducted with galantamine and memantine for CIAS and to highlight the efficacy signal. A perception remains in the field that galantamine and memantine were found to be ineffective in schizophrenia, yet there are many reasons why this combination is worth trying if the studies are well designed. This article sheds light on the possibility that these RCTs failed to detect a clinically meaningful efficacy signal due to limitations, methodological issues, and possible medication nonadherence [49]. This objective coincides with the new National Institutes of Health policy on how to address scientific premise to enhance reproducibility through rigor and transparency [50,51].

\section{Methods}

PubMed and Google Scholar were searched using the keywords schizophrenia, cognition, galantamine, memantine, and guidelines. RCTs published to date as of this writing were included. Twelve RCTs published in English (7 on galantamine and 5 on memantine) were identified and are summarized in Table 1. Five other RCTs on memantine did not assess cognition [52-56] and are not included in Table 1.

\section{Limitations of the FDA-NIMH-MATRICS Guidelines}

Although the US Food and Drug Administration National Institute of Mental Health MATRICS (FDANIMH-MATRICS) provide comprehensive guidelines on how to conduct clinical trials for cognitive enhancement in schizophrenia $[57,58]$, several issues have not been addressed. For example, the age criterion for a proof-of-concept study is not mentioned in the guidelines. Hence, the upper age limit in RCTs has been inconsistent and has ranged from 50 to 70 years. Also, the guidelines do not provide an adequate duration for a proof-of-concept study. Two-thirds of the studies with galantamine and memantine identified in this article had a duration $\geq 12$ weeks. Among the 4 studies [59-62] with a duration $<12$ weeks, only one was associated with an efficacy signal [59]. Among 118 RCTs on CIAS, a large majority had a duration $\leq 8$ weeks [63]. These findings shed light on the importance of adequate study duration to detect an efficacy signal. Additionally, the updated guidelines [58] recommend the inclusion of participants taking up to two antipsychotics. This recommendation is nonspecific with no limitation on the maximum dose allowed. With this criterion, a participant taking haloperidol $60 \mathrm{mg}$ and risperidone $16 \mathrm{mg}$ could be enrolled in a study, and these high doses may interfere with signal detection [64]. Administration of chlorpromazine-equivalent doses $\geq 1,000 \mathrm{mg} /$ day, which is suggestive of treatment resistance [65], lowers the likelihood of detecting a signal on cognition [66]. Furthermore, the guidelines suggest adding any two antipsychotics if there are no pharmacokinetic or pharmacodynamic considerations but provide no specific examples of which two antipsychotics should not be combined. The only concern, although not mentioned in the guidelines, may be combining thioridazine with other antipsychotics because of the possibility of QTc prolongation; however, participants taking thioridazine should be excluded because of the drug's significant anticholinergic activity (AA). The guidelines only mention excluding participants taking clozapine and a high dose of olanzapine, which is not defined. It should be noted that thioridazine has more AA than olanzapine [67]. Finally, FDA-NIMH-MATRICS provide no guidelines on the electroconvulsive therapy (ECT) criterion. Among all the studies in Table 1, only one excluded those who received ECT in the past 2 weeks [68]. Ideally, subjects should be excluded from a study if they received ECT in the past 6 months so that they have time to recover from the associated cognitive impairments [69].

\section{Lack of Adherence to the FDA-NIMH-MATRICS Guidelines}

On the basis of the limitations and methodological issues of the studies presented in Table 1 , it is clear that the FDA-NIMH-MATRICS guidelines were not stringently followed. However, several of the studies were in progress before the guidelines were published. The inclusion and exclusion criteria became less stringent in the second version of the guidelines, in part, because of the recruitment challenge, and revisions were made to address feasibility issues, while still maintaining methodological rigor. A few specific issues are addressed below. 
Table 1. Randomized controlled trials of galantamine and memantine in schizophrenia

\begin{tabular}{|c|c|c|c|}
\hline $\begin{array}{l}\text { First author [Ref.], } \\
\text { year and country } \\
\text { where study was } \\
\text { conducted }\end{array}$ & $\begin{array}{l}\text { Mean Age, years } \\
\text { (range)/sample size } \\
\text { (drug, placebo) } / \\
\text { duration, weeks/ } \\
\text { cognitive assessment }\end{array}$ & $\begin{array}{l}\text { Significant efficacy } \\
\text { signal in cognition }\end{array}$ & Limitations and methodological issues \\
\hline $\begin{array}{l}\text { Galantamine } 24 \mathrm{mg} \\
\text { Schubert [59], } \\
2006, \text { USA }\end{array}$ & $\begin{array}{l}48.3(26-55) / \\
8,6 / 8 / \\
\text { RBANS }\end{array}$ & $\begin{array}{l}\text {-Delayed memory } \\
\text { and attention (increase } \\
\text { in RBANS total score = } \\
12.1 \text { ) }\end{array}$ & $\begin{array}{l}\text {-Small sample size } \\
\text {-24 mg only for } 4 \text { weeks } \\
\text {-SUD only within } 30 \text { days excluded; recommended guideline is last } 6 \text { months } \\
\text {-Excluded use of any anticholinergic or psychotropic medications; this is too } \\
\text { nonspecific } \\
\text {-Jadad score: } 3\end{array}$ \\
\hline $\begin{array}{l}\text { Lee [86], } 2007 \\
\text { (galantamine } 16 \mathrm{mg} \text { ), } \\
\text { Korea }\end{array}$ & $\begin{array}{l}39.5 \text { (range } \\
\text { unavailable)/ } \\
12,12 / 12 / \text { standard } \\
\text { neuro- } \\
\text { psychological battery }\end{array}$ & $\begin{array}{l}\text {-Visual learning } \\
\text { (Rey Complex Figure } \\
\text { Test score 5.7-6.4) }\end{array}$ & $\begin{array}{l}\text {-Small sample size } \\
\text {-16 mg only for } 6 \text { weeks } \\
\text {-Inpatients with an average BPRS score of } 55 \text { with an average CPZ dose } \\
\text { equivalence of } 1,280 \text { mg in those who received galantamine } \\
\text {-Only those with MMSE scores } 18-24 \text { were included } \\
\text {-Dose of anticholinergics not defined } \\
\text {-SUD not excluded } \\
\text {-Jadad score: } 1\end{array}$ \\
\hline $\begin{array}{l}\text { Buchanan [89], 2008, } \\
\text { USA }\end{array}$ & $\begin{array}{l}49.9(18-60) / \\
35,38 / 12 / \\
8 \text {-test } \\
\text { neuropsychological } \\
\text { battery }\end{array}$ & $\begin{array}{l}\text {-Processing speed } \\
\text { (digit symbol score: } \\
\text { 5.8-6.7) } \\
\text {-Verbal learning: } \\
7.1-7.8\end{array}$ & $\begin{array}{l}\text { - } 24 \text { mg only for } 4 \text { weeks } \\
\text {-Out of } 42 \text { patients on galantamine ( } 35 \text { completed the study), } 32 \text { were outpatients } \\
\text { and } 10 \text { were inpatients; out of } 44 \text { on placebo ( } 38 \text { completed the study), } 31 \text { were } \\
\text { outpatients and } 13 \text { were inpatients; acutely sick patients in the inpatient setting } \\
\text { are not the ideal target population for a proof-of-concept cognition enhancement } \\
\text { study } \\
\text {-Only those with RBANS total score } \leq 90 \text { were included; this may have excluded } \\
\text { the cognitive enhancement among those with scores } 91-99 \\
\text {-BPRS total and positive symptoms scores were not defined in the inclusion } \\
\text { criteria } \\
\text {-Those on a low dose of typical antipsychotic were included; low dose was not } \\
\text { defined } \\
\text {-Those with anticholinergic treatment were excluded; other anticholinergic } \\
\text { medications were not excluded } \\
\text {-Jadad score: } 4\end{array}$ \\
\hline $\begin{array}{l}\text { Dyer [60], } 2008 \\
\text { (galantamine } 32 \\
\text { mg),USA }\end{array}$ & $\begin{array}{l}44.3(18-60) / 9,9 / 8 / \\
\text { neuropsychological } \\
\text { tests }\end{array}$ & $\begin{array}{l}\text {-Several cognitive } \\
\text { measures worsened } \\
\text { on galantamine }\end{array}$ & $\begin{array}{l}\text {-Small sample size } \\
\text {-Clozapine was included } \\
\text {-32 mg has an antagonistic action } \\
\text {-PANSS total and positive symptoms scores were not defined in the inclusion } \\
\text { criteria } \\
\text {-Those on anticholinergic medication were excluded; however, details were not } \\
\text { given } \\
\text {-Jadad score: } 4\end{array}$ \\
\hline $\begin{array}{l}\text { Lindenmayer [70], } \\
\text { 2011, USA }\end{array}$ & $\begin{array}{l}41.9(18-70) / 7,9 / 26 / \\
\text { computerized test } \\
\text { battery (Cogtest) }\end{array}$ & $\begin{array}{l}\text {-Worsening of } \\
\text { social cognition } \\
\text { on galantamine }\end{array}$ & $\begin{array}{l}\text {-Small sample size } \\
\text {-Including participants up to age } 70 \text { years may have obscured to detect a signal } \\
\text {-Inclusion of PANSS scores } 5-7 \text { may have attenuated to detect a signal } \\
\text {-No mention about SAS and CDSS in the criteria }{ }^{b} \\
\text {-Dose of anticholinergics and details regarding the use were not clearly } \\
\text { documented } \\
\text {-Medications with significant anticholinergic activity were not excluded } \\
\text {-PEAT may not be the ideal test to measure social cognition; MCCB uses } \\
\text { MSCEIT, which was not a part of MCCB when this study was done } \\
\text {-Jadad score: } 4\end{array}$ \\
\hline
\end{tabular}


Table 1 (continued)

\begin{tabular}{|c|c|c|c|}
\hline $\begin{array}{l}\text { First author [Ref.], } \\
\text { year and country } \\
\text { where study was } \\
\text { conducted }\end{array}$ & $\begin{array}{l}\text { Mean Age, years } \\
\text { (range)/sample size } \\
\text { (drug, placebo) }{ }^{\mathrm{a}} / \\
\text { duration, weeks/ } \\
\text { cognitive assessment }\end{array}$ & $\begin{array}{l}\text { Significant efficacy } \\
\text { signal in cognition }\end{array}$ & Limitations and methodological issues \\
\hline $\begin{array}{l}\text { Deutsch [72], 2013, } \\
\text { USA }\end{array}$ & $\begin{array}{l}54.4(18-70) / \\
15,19 / 16 / \\
\text { MCCB }\end{array}$ & $\begin{array}{l}\text {-Verbal learning } \\
\text { (13.0-13.9 in spatial } \\
\text { span) } \\
\text {-Significant } \\
\text { improvement in the } \\
\text { scale of functioning }\end{array}$ & $\begin{array}{l}\text {-Including participants up to age } 70 \text { years may have obscured to detect a signal } \\
\text {-Only those who had a score of at least } 4 \text { (moderate) on at least one of the } \\
\text { following five PANSS negative symptom items were included: blunted affect, } \\
\text { emotional withdrawal, poor rapport, passive/apathetic social withdrawal, and lack } \\
\text { of spontaneity and flow of conversation } \\
\text {-Excluded those with the PANSS positive symptom score for conceptual } \\
\text { disorganization, hallucinations, suspiciousness, and delusions that exceeded 18; } \\
\text { no cutoff score provided for each item; this could have potentially led to } \\
\text { participants with a score of 6-7 being enrolled, which is not ideal for a proof-of- } \\
\text { concept study } \\
\text {-Anticholinergic medications were not excluded SUD excluded within three } \\
\text { months of enrollment (guidelines recommend } 6 \text { months) } \\
\text {-Jadad score: } 4\end{array}$ \\
\hline
\end{tabular}

Memantine $20 \mathrm{mg}$

Lieberman [61], 2009, $40.9(18-65) / 61,56 / 8 /$

USA

\section{-None}

-Focus of the study was on persistent residual psychopathology and not on cognition
-Participants up to age 65 years may have attenuated a signal detection in BACS -Received memantine $20 \mathrm{mg}$ only for 6 weeks

-Only included participants with BPRS total score $\geq 26$ and score $\geq 4$ on at least one of the BPRS psychosis factor items: conceptual disorganization, hallucinatory behavior, suspiciousness, and unusual thought content

-Did not exclude anticholinergic medications

-Jadad score: 3 
Table 1 (continued)

\begin{tabular}{|c|c|c|c|}
\hline $\begin{array}{l}\text { First author [Ref.], } \\
\text { year and country } \\
\text { where study was } \\
\text { conducted }\end{array}$ & $\begin{array}{l}\text { Mean Age, years } \\
\text { (range)/sample size } \\
\text { (drug, placebo) }{ }^{\mathrm{a}} / \\
\text { duration, weeks/ } \\
\text { cognitive assessment }\end{array}$ & $\begin{array}{l}\text { Significant efficacy } \\
\text { signal in cognition }\end{array}$ & Limitations and methodological issues \\
\hline $\begin{array}{l}\text { de Lucena [87], 2009, } \\
\text { Brazil }\end{array}$ & $\begin{array}{l}34.7(18-65) / \\
10,11 / 12 / \\
\text { MMSE }\end{array}$ & $\begin{array}{l}\text {-MMSE scores } \\
\text { increased from } 22.3 \text { to } \\
28.2 \text {, effect size }(\mathrm{ES})= \\
1.32 \text { and } p=0.005 \\
\text {-Focus of the study was } \\
\text { on negative symptoms } \\
\text { and not on cognition } \\
\text {-Improvement in CIAS } \\
\text { despite having high } \\
\text { scores on BPRS positive } \\
\text { and negative symptoms }\end{array}$ & $\begin{array}{l}\text {-Significant improvement in cognition despite including age up to } 65 \text { years } \\
\text {-Small sample size } \\
\text {-Received memantine } 20 \mathrm{mg} \text { only for } 9 \text { weeks } \\
\text {-SAS score } 6.4 \pm 3.4 \text { may have attenuated with the signal detection; } \\
\text { FDA-NIMH-MATRICS guidelines recommend including participants' SAS } \\
\text { score } \leq 6 \\
\text {-MMSE is not a valid instrument for measuring cognitive impairments associated } \\
\text { with schizophrenia (CIAS) } \\
\text {-Jadad score: } 3\end{array}$ \\
\hline $\begin{array}{l}\text { Veerman [88], } \\
\text { 2016, Netherlands }{ }^{c}\end{array}$ & $\begin{array}{l}42.4(18-60) / \\
23,21 / 12 / \\
\text { CANTAB }\end{array}$ & $\begin{array}{l}- \text { Verbal }(E S=0.5) \\
\text { and visual }(E S=0.3) \\
\text { learning }\end{array}$ & $\begin{array}{l}\text {-Small sample size } \\
\text {-Crossover study design with carry-over effects } \\
\text {-Six inpatients were included } \\
\text {-SUD was not excluded } \\
\text {-Anticholinergics and medications with anticholinergic activity were not } \\
\text { excluded } \\
\text {-No mention of SAS and CDSS in the inclusion/exclusion criteria } \\
\text {-CANTAB assessed six domains in MCCB (reasoning and problem solving were } \\
\text { not assessed) } \\
\text {-Practice effects of CANTAB are unknown; however, the study had memantine } \\
\text { and placebo arms } \\
\text {-Jadad score: } 5\end{array}$ \\
\hline $\begin{array}{l}\text { Mazinani [68], 2017, } \\
\text { Iran }\end{array}$ & $\begin{array}{l}44.8(18-55) / \\
18,18 / 12 / \\
\text { MMSE }\end{array}$ & $\begin{array}{l}\text {-MMSE score } \\
\text { increased from } \\
26.3 \text { to } 28.2\end{array}$ & $\begin{array}{l}\text {-Small sample size } \\
\text {-Inpatients not in an acute phase were enrolled } \\
\text {-PANSS positive symptoms scores were not clearly defined in the inclusion } \\
\text { criteria } \\
\text {-No mention of SAS, CDSS, or anticholinergic medications in the inclusion/ } \\
\text { exclusion criteria } \\
\text {-Excluded those who received ECT in the past } 2 \text { weeks; ideally, patients who } \\
\text { received ECT in the past six months should be excluded to recover from amnesia } \\
\text {-MMSE is not a valid instrument for measuring cognition in schizophrenia } \\
\text {-Jadad score: } 5\end{array}$ \\
\hline
\end{tabular}

BACS, Brief Assessment of Cognition in Schizophrenia; BPRS, Brief Psychiatric Rating Scale; CANTAB, Cambridge Neuropsychological Test Automated Battery; CDSS, Calgary Depression Scale for Schizophrenia; CIAS, cognitive impairments associated with schizophrenia; CPZ, chlorpromazine; ECT, electroconvulsive therapy; MCCB, MATRICS Consensus Cognitive Battery; MMSE, Mini-Mental State Examination; MSCEIT, Mayer-Salovey-Caruso Emotional Intelligence Test; PANSS, Positive and Negative Syndrome Scale; PEAT, Penn Emotional acuity Test; RBANS, Repeatable Battery for Assessment of Neuropsy-

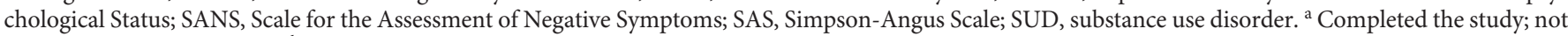
intent-to-treat sample [167]. ${ }^{\mathrm{b}}$ Several authors did not mention some information/variables/criteria in their papers. It is unclear whether they did include those information/variables/criteria in their study and did not mention it in the article or did not include them at all in their study. ${ }^{\mathrm{c}}$ An open-label 1-year extension study $(n=24)$ had sustained effect on verbal and visual learning [168]. The Jadad score is a 7 -item scale to assess the methodological quality of RCTs. Scores range from 0 to 5 ; higher scores indicate superior quality. Ease of use and brevity are advantages. A score of 5 does not rule out other limitations of the study. 


\section{Substance Use Disorder}

Among all the studies in Table 1, only 2 conducted a urine drug screen (UDS) at baseline to exclude people with substance use disorder (SUD) [61,70]; one study conducted a salivary drug screen [60]. A negative UDS at baseline is recommended as an inclusion criterion in the latest FDA-NIMH-MATRICS guidelines for proof-ofconcept studies for cognitive enhancement in schizophrenia. Historical evidence is not sufficient to rule out SUD. The UDS does not assess alcohol use disorder. A UDS dip test is available and easy to complete; however, some studies may not have conducted the test due to monetary constraints. Another reason for not including the UDS is that the first FDA-NIMH-MATRICS guidelines did not mention SUD. However, inclusion of participants with SUD is likely to interfere with signal detection $[58,71]$. The second version of the guidelines recommends that the project investigator use clinical judgment to decide whether to include a participant who tests positive on a UDS at the end of the study, as it may affect the sample size. The second version also uses the term "illicit." In one study, those with a history of illicit drug use in the past 6 months were excluded [68]. However, the term illicit is misleading because alcohol is licit, thus it is unclear whether those with alcohol use disorder in the last 6 months were excluded, which is a requirement.

\section{Rating Scales}

Of 12 studies, only $2[62,72]$ used the MATRICS Consensus Cognitive Battery (MCCB [73]). It is unclear how cognitive rating scales used in the other studies would translate to changes in the MCCB. The MCCB also has limitations - important cognitive measures such as sensory gating, mismatch negativity (MMN) [74, 75], and cortical oscillatory response dynamics/gamma oscillations [76] are not captured by the scale.

Most of the studies in Table 1 used the BPRS [77] or 4-item PANSS [78] to measure psychoses. In the BPRS positive symptoms, it is redundant to use the item suspiciousness. Suspiciousness is captured in the unusual thought content item; thus, capturing the data twice may lead to a falsely increased score, and the participant may not fulfill the criteria for enrollment in the study. Hallucination is captured and documented as a composite score; it is not scored in all of the five sensory modalities. The same analogy can be made for delusion as well. The FDA-NIMH-MATRICS guidelines recommend using only three items to measure psychoses. The BPRS 3-item (hallucinatory behavior, unusual thought content, con- ceptual disorganization), which captures all of the psychoses items, has been used successfully $[79,80]$.

Only one study in Table 1 conducted a measurement of functional capacity [62]. The FDA-NIMH-MATRICS guidelines recommend using UCSD Performance-Based Skills Assessment (UPSA)-2 [81]. None of the studies in Table 1 used Calgary Depression Scale for Schizophrenia (CDSS [82]) scores $\leq 10$ as an inclusion criterion, which is recommended by the guidelines. Also, no studies excluded medications that have significant AA [67] that can affect signal detection $[83,84]$.

\section{Miscellaneous Issues}

Of the 12 studies, only one had an adequate sample size [61], and it was a multicenter study. It is important to note that single-site studies are limited by small sample size because of the recruitment and retention challenge. Rather than adjusting the inclusion and exclusion criteria to enhance recruitment [49], a multicenter or multinational $(n=319$; [80]) study with an adequate sample size and stringent criteria may provide clinically valid results. As shown in Table 1, it is difficult to draw a firm conclusion from a failed study with a small sample size and several limitations and methodological issues. Studies often report the intent-to-treat (ITT) sample as the final sample size. Ideally, those who completed the study should be reported as the final sample size. There is a large discrepancy between the ITT sample size and the number who completed the study. In one study [70], the ITT sample was 32 , and only 16 completed the study; $n=32$ is reported as the final sample size, which is misleading. The last-observation-carried-forward results may not be as valid as those in participants who completed the study [48].

Four studies enrolled only participants with schizophrenia [68, 85-87]. Two studies excluded those with schizoaffective disorder, bipolar type [59-60], and one study excluded those with schizoaffective disorder [88]. The rationale for these exclusions was not described. The FDA-NIMH-MATRICS guidelines recommend including schizophrenia and schizoaffective disorder.

Of the 12 studies, only 2 documented adherence [62, 89]. However, both studies used a weekly pill count and medication review to check for adherence, which is not a foolproof method [90], and only participants who received $75 \%$ or more of their assigned study medication were included in the analysis $[62,89]$. Efficacy signal detection may be enhanced in future RCTs if all of these issues are addressed. 


\section{Issues for Future Studies}

For an ideal proof-of-concept cognition enhancement study, the age criterion would be 18-40 years (clinicaltrials.gov NCT02008773; this is a multicenter study). However, for a proof-of-concept study, considering the recruitment challenge and for feasibility reasons, 18-55 years would be acceptable (ClinicalTrials.gov Identifier: NCT02234752). For example, in a phase 2 study with encenicline for CIAS [80], 18-55 years was used as the age criterion. For phase 3 studies, 18-64 years may be used. To ensure consistency and interpretation of results between studies, these arbitrary age ranges would be ideal. Also, to detect an efficacy signal, the duration of the study should be at least 12 weeks [80]. Keep in mind that several weeks are needed for titration of medications to reach the maximum dose. If 12 weeks is not feasible due to monetary reasons, a 4 - to 12 -week study may be conducted [91]. A limit of chlorpromazine $1,000 \mathrm{mg} /$ day equivalence may be used. Also, the maximum dose of an antipsychotic allowed should be no more than what is recommended in the package insert; none of the studies in Table 1 mentioned this. Medications with significant AA (>15 $\mathrm{pmol} / \mathrm{mL}$ ) such as amitriptyline, atropine, clozapine, dicyclomine, doxepin, L-hyoscyamine, thioridazine, and tolterodine [67] should be excluded in phase 2 treatment studies for CIAS. It may be a good idea to exclude participants if they are on two or more of the following: chlorpromazine, diphenhydramine, nortriptyline, olanzapine, oxybutynin, and paroxetine (AA values of 5-15 $\mathrm{pmol} / \mathrm{mL}$ [67]). It may be worthwhile to conduct a gamma-glutamyl transferase test to capture alcohol use disorder; nail and hair analyses are not feasible. ECT within 6 months as an exclusion criterion may be added.

\section{Kynurenine Pathway}

Kynurenic acid (KYNA) is an antagonist of the NMDA $[92,93]$ and $\alpha 7 \mathrm{nACh}$ receptors [94]. There is mounting evidence regarding the role of the kynurenine pathway (KP) in schizophrenia [95, 96] and CIAS [97]. The KYNA hypothesis in schizophrenia is well documented $[98,99]$. The galantamine-memantine combination may be effective for CIAS with KYNA as a biomarker to detect the severity of cognitive impairments and monitor progress (target engagement) with treatment $[100,101]$. There is also evidence from a small open-label study that this combination may be effective for CIAS with concurrent improvement in KP metabolite concentrations [102]. In that

Antipsychotic-Galantamine-Memantine

Combination for Schizophrenia Treatment study, reduction of KYNA concentration was seen in all participants [102]. Decreased concentration of KYNA may be important not only for cognition but also for psychosis because increased KYNA concentration may be associated with psychosis [103-105]. Furthermore, inhibition of kynurenine aminotransferase II was associated with a marked reduction in dopamine firing activity in the ventral tegmental area [106]. KP modulations may be potential targets of novel antipsychotics [107]. Finally, KYNA levels bidirectionally modulate levels of neurotransmitters such as glutamate, dopamine, acetylcholine, and GABA [97, 108-114].

\section{Negative Symptoms}

Thirty-six patients with $\mathrm{AD}$ who did not respond to treatment with donepezil were switched to galantamine and followed for 24 weeks. Apathy and executive functioning improved significantly [115]. Thirty-one participants with schizophrenia received 3-(2,4-dimethoxybenzylidene) anabaseine (DMXB-A), which is a partial $\alpha 7$ nicotinic agonist. Those who received DMXB-A $150 \mathrm{mg}$ twice daily had significant improvement in SANS total, anhedonia, and alogia scores (significant improvement in attention/vigilance and working memory) compared to those who received DMXB-A $75 \mathrm{mg}$ twice daily or placebo [116]. In an RCT of galantamine in schizophrenia $(n=86)$, galantamine significantly improved alogia compared to placebo [89], which is not surprising since galantamine has been shown to improve primary progressive aphasia in frontotemporal dementia [117]. Galantamine administration had a beneficial effect on chronic poststroke aphasia in 45 patients [118]. Nicotinic action consistently improves alogia, which is an intriguing finding. In an RCT in schizophrenia $(n=185)$, an $\alpha 7$ nicotinic receptor agonist significantly improved executive functioning and the SANS total score compared to placebo [119]. In another RCT of encenicline (an $\alpha 7$ nicotinic partial agonist) in schizophrenia, negative symptoms significantly improved $(d=0.33)$ with encenicline $0.9 \mathrm{mg}(n=105)$ compared to 105 on placebo [80]. Finally, in another RCT in schizophrenia $(n=215)$, an $\alpha 7$ nicotinic agonist significantly improved total negative symptoms compared to placebo [120].

Memantine treatment reversed anhedonia in stressed rats [121]. Memantine was administered to neonatal rats with early maternal deprivation; social interaction was significantly enhanced in adult rats [122]. In an RCT with 28 chronic poststroke patients, memantine was effective for aphasia [123]. In a 52-year-old man with schizophre- 
Table 2. Meta-analysis of RCTs with galantamine and memantine in schizophrenia: efficacy signal

\begin{tabular}{llll}
\hline Studies & Positive symptoms & Cognitive symptoms & Negative symptoms \\
\hline $\begin{array}{l}\text { Koola et al. [41], } \\
\text { Galantamine } \\
6 \text { studies }(n=226)\end{array}$ & $\begin{array}{l}\text { Effect size Hedges' } g=-0.076 \\
\text { (improved) } \\
\text { not significant }\end{array}$ & $\begin{array}{l}\text { Effect size Hedges' } g=0.233, p<0.001 \\
5 \text { studies: effect size }=0.269\end{array}$ & $\begin{array}{c}\text { Effect size Hedges' } g=-0.107 \\
\text { (improved) not significant }\end{array}$ \\
$\begin{array}{l}\text { Kishi et al. [42], 2017 } \\
\begin{array}{l}\text { Memantine } \\
8 \text { studies }(n=448)\end{array}\end{array}$ & SMD $=0.46, p=0.07$ & MD $=3.07, p<0.0001$ & SMD $=0.96, p=0.006$ \\
$\begin{array}{l}\text { Zheng et al. }[43], 2018 \\
\begin{array}{l}\text { Memantine } \\
8 \text { studies }(n=452)\end{array}\end{array}$ & $\begin{array}{l}\text { SMD }=0.12 \\
\text { not significant }\end{array}$ & Weighted MD $=3.09, p<0.00001$ & SMD $=0.63, p=0.009$ \\
\hline
\end{tabular}

$\mathrm{MD}$, mean difference; SMD, standardized mean difference. If we combine the meta-analysis findings of galantamine and memantine (let alone synergy), we are likely to get a clinically significant efficacy signal with an effect size of at least 0.8 for positive, cognitive, and negative symptoms.

nia, memantine $20 \mathrm{mg}$ daily for 2 months decreased SANS scores from 96 to 70 (avolition-apathy: -8 , anhedoniaasociality: -7 , affective flattening: -7 , alogia: -1 , and at tention: -3$)$ in 4 months [124]. Participants with deficit schizophrenia $(n=40)$ showed increased IgA responses to KP metabolites such as xanthurenic acid, picolinic acid, and quinolinic acid and relatively lowered IgA responses to KYNA and anthranilic acid compared to healthy controls $(n=40)$ and 40 subjects with nondeficit schizophrenia [125]. In a meta-analysis of 8 RCTs $(n=$ 448) in schizophrenia [42], memantine significantly improved negative symptoms compared to placebo $(\mathrm{SMD}=$ $0.96, p=0.006$ ).

Eugen Bleuler's four As include affect, autism, ambivalence, and associations. Both galantamine (or medications acting at the nicotinic receptor) and memantine consistently improve affect, autism, and ambivalence, which is termed negative symptoms in the current literature. In a 6-week open-label study in schizophrenia with the galantamine-memantine combination, the SANS total score improved from 5 to 0 in one participant [102]. This finding is suggestive of primary negative symptoms because the BPRS psychosis, CDSS, and Simpson-Angus Scale scores were 4,0 , and 0 (all minimum scores), respectively. Medications that act at the NMDA receptor have been suggested as potential treatments for both negative symptoms and CIAS [126]. Therefore, use of the galantamine-memantine combination to treat negative symptoms is an additional benefit. Finally, to treat negative symptoms in schizophrenia, medications that target the glutamatergic system and $\alpha 7 \mathrm{nACh}$ receptors are hypothesized to yield positive results [127-129].

\section{Mismatch Negativity}

MMN is a neurophysiological response elicited by a sequence of repetitive standard stimuli that is interrupted infrequently by a physically different oddball stimulus. MMN functioning [130] occurs via interaction of NMDA [131] and $\alpha 7 \mathrm{nACh}$ receptors [132-134]. In addition, smaller MMN amplitude was significantly associated with lower GABA and glutamate (measured by magnetic resonance spectroscopy) level in 45 people with schizophrenia compared to 53 healthy controls [135]. MMN deficits are tied to poor functional outcome [136, 137], as recently confirmed in a study of 1,415 subjects with schizophrenia. In this study, early auditory processing event-related potential (MMN, P300, and reorienting negativity) predicted cognition $(\beta=0.37, p<0.001)$, while cognition itself directly predicted negative symptoms $(\beta=-0.16, p<0.001)$ and indirectly predicted functional outcome [138]. Furthermore, MMN is highly predictive of response to auditory cognitive remediation [139]. MMN was found to be a sensitive and predictive biomarker of perceptual learning during auditory cognitive training in 28 individuals with schizophrenia [140]. MMN was enhanced in 13 healthy subjects with memantine $30 \mathrm{mg}$ (Cohen's $d=0.87$; [141]), in rodents with memantine $10 \mathrm{mg} / \mathrm{kg}$ [142], and in 41 people with schizophrenia with memantine $20 \mathrm{mg}$ [75]. No studies have been conducted with galantamine on MMN. However, an RCT of encenicline in schizophrenia showed a dose-dependent increase in MMN [143]. Interactive effects of the a7nACh and NMDA receptors on MMN are well documented [144-146]. MMN is not only a cognitive bio- 
marker but also a biomarker for negative symptoms in schizophrenia [147]. The pharmacology of cognition as a panacea for neuropsychiatric diseases was recently published [148]. This is important because neuropsychological tests were unable to distinguish CIAS versus cognitive impairments after traumatic brain injury [149]. MMN could be a potential biomarker with the galantamine-memantine combination in the treatment and prevention of schizophrenia $[150,151]$.

\section{Summary and Future Directions}

In the meta-analysis described previously, positive symptoms in schizophrenia improved at a trend level ( $p=0.07)$ with memantine compared to placebo [42]. NMDA receptor dysfunction and dysregulation have been proposed as the final common pathway of positive, cognitive, and negative symptoms in schizophrenia [152]. Use of the positive allosteric modulator of $\alpha 7 \mathrm{nAChR}$ to target positive, cognitive, and negative symptoms in schizophrenia is well documented [153-157]. Therefore, the galantamine-memantine combination has the potential to treat positive, cognitive, and negative symptoms of schizophrenia as shown in Table 2. The major pathophysiological mechanisms of cognitive and negative symptoms, KYNA, MMN, and BDNF $[158,159]$ are NMDA and nicotinic receptors. Although there is a diversity of biomarkers focused on CIAS, BDNF has accumulated the vast majority of evidence [160]. The galantamine-memantine combination has the potential to target both receptors concurrently, which is a paradigm shift in the treatment of schizophrenia since historically only one receptor (NMDA or nicotinic with partial treatment response) has been targeted at a time. Given that there are no available treatments for CIAS and negative symptoms, testing of quintuple hypotheses (dopamine, nicotiniccholinergic, glutamatergic/NMDA, GABA, and KYNA) is a "low-risk high-gain" approach that could significantly advance our field. Multitarget drug discovery may play a role in the treatment of complex diseases [161] including, but not limited to, schizophrenia $[100,162]$.

The field should focus on all of the studies that showed an efficacy signal from one medication despite having methodological issues. Adequately powered, at least 12week, well-designed RCTs (proof-of-concept study: galantamine-memantine combination versus galantamine-placebo or memantine-placebo) using galantamine $24 \mathrm{mg}$ daily and memantine $28 \mathrm{mg}$ daily to enhance efficacy [163], and stringently following the FDA-NIMHMATRICS guidelines with this combination may significantly enhance cognition. In medicine, combination treatment is the rule rather than the exception. Psychiatry has lagged behind other specialties with regard to obtaining approval for combination treatments. If results of future RCTs are positive, "repurposing" of these already approved medications could lead to rapid clinical implementation.

Imbalance in one system (neurotransmitter/receptor/ pathway) affects the entire system [164]. Hence, a reversal of anomalous activity in one system, or any combinations thereof, may have beneficial effects on the entire system [49]. After all, at the end of the day, schizophrenia is dementia praecox, weakening of volition [165], and Bleuler's 4 As. The field may be able to move beyond antipsychotic treatment towards "antischizophrenia" treatment [166] via the quintuple hypotheses strategy.

\section{Disclosure Statement}

The author declares no conflict of interest.

\section{Funding Sources}

There was no funding for the manuscript preparation.

\section{References}

Antipsychotic-Galantamine-Memantine

Combination for Schizophrenia Treatment
1 Kahn RS, Keefe RS. Schizophrenia is a cognitive illness: time for a change in focus. JAMA Psychiatry. 2013 Oct;70(10):1107-12.

2 Green MF, Kern RS, Braff DL, Mintz J. Neurocognitive deficits and functional outcome in schizophrenia: are we measuring the "right stuff"? Schizophr Bull. 2000;26(1):119-36.

3 Tandon R. Cholinergic aspects of schizophrenia. Br J Psychiatry Suppl. 1999;174(37):7-11.
4 Tracy JI, Monaco C, Giovannetti T, Abraham G, Josiassen RC. Anticholinergicity and cognitive processing in chronic schizophrenia. Biol Psychol. 2001 Mar;56(1):1-22.

5 Kim JS, Kornhuber HH, Schmid-Burgk W, Holzmüller B. Low cerebrospinal fluid glutamate in schizophrenic patients and a new hypothesis on schizophrenia. Neurosci Lett. 1980 Dec;20(3):379-82. 
6 Goff DC, Coyle JT. The emerging role of glutamate in the pathophysiology and treatment of schizophrenia. Am J Psychiatry. 2001 Sep; 158(9):1367-77.

7 Leonard S, Adams C, Breese CR, Adler LE, Bickford P, Byerley W, et al. Nicotinic receptor function in schizophrenia. Schizophr Bull. 1996;22(3):431-45.

8 Krystal JH, D'Souza DC, Mathalon D, Perry E, Belger A, Hoffman R. NMDA receptor antagonist effects, cortical glutamatergic function, and schizophrenia: toward a paradigm shift in medication development. Psychopharmacology (Berl). 2003 Sep;169(3-4):21533.

9 Buchanan RW, Freedman R, Javitt DC, AbiDargham A, Lieberman JA. Recent advances in the development of novel pharmacological agents for the treatment of cognitive impairments in schizophrenia. Schizophr Bull. 2007 Sep;33(5):1120-30.

10 Samochocki M, Zerlin M, Jostock R, Groot Kormelink PJ, Luyten WH, Albuquerque EX, et al. Galantamine is an allosterically potentiating ligand of the human alpha4/beta2 nAChR. Acta Neurol Scand Suppl. 2000;176 s176:68-73.

11 Johnson JW, Kotermanski SE. Mechanism of action of memantine. Curr Opin Pharmacol. 2006 Feb;6(1):61-7.

12 Parsons CG, Danysz W, Quack G. Memantine is a clinically well tolerated N-methyl-Daspartate (NMDA) receptor antagonist-a review of preclinical data. Neuropharmacology. 1999 Jun;38(6):735-67.

13 Aramakis VB, Metherate R. Nicotine selectively enhances NMDA receptor-mediated synaptic transmission during postnatal development in sensory neocortex. J Neurosci. 1998 Oct;18(20):8485-95.

14 Radcliffe KA, Dani JA. Nicotinic stimulation produces multiple forms of increased glutamatergic synaptic transmission. J Neurosci. 1998 Sep;18(18):7075-83.

15 Moriguchi S, Marszalec W, Zhao X, Yeh JZ, Narahashi T. Mechanism of action of galantamine on N-methyl-D-aspartate receptors in rat cortical neurons. J Pharmacol Exp Ther. 2004 Sep;310(3):933-42.

16 Grossberg GT, Edwards KR, Zhao Q. Rationale for combination therapy with galantamine and memantine in Alzheimer's disease. J Clin Pharmacol. 2006 Jul;46(7 Suppl 1): 17S-26S.

17 Geerts H, Grossberg GT. Pharmacology of acetylcholinesterase inhibitors and N-methyl-D-aspartate receptors for combination therapy in the treatment of Alzheimer's disease. J Clin Pharmacol. 2006 Jul;46(7 Suppl 1): $8 S-16 S$.

$18 \mathrm{Li} \mathrm{H}$, Matsumoto K, Watanabe H. An alphaamino-3-hydroxy-5-methyl-4-isoxazolepropionic acid (AMPA) antagonist and an $\mathrm{N}$ methyl-D-aspartate (NMDA) channel blocker synergistically impair spatial memory in rats. Biol Pharm Bull. 1998 Nov;21(11):122830.
19 Santos MD, Alkondon M, Pereira EF, Aracava Y, Eisenberg HM, Maelicke A, et al. The nicotinic allosteric potentiating ligand galantamine facilitates synaptic transmission in the mammalian central nervous system. Mol Pharmacol. 2002 May;61(5):1222-34.

20 Moriguchi S, Ishizuka T, Yabuki Y, Shioda N, Sasaki Y, Tagashira H, et al. Blockade of the KATP channel Kir6.2 by memantine represents a novel mechanism relevant to Alzheimer's disease therapy. Mol Psychiatry. 2018 Feb;23(2):211-21.

21 Golime R, Palit M, Acharya J, Dubey DK. Neuroprotective Effects of Galantamine on Nerve Agent-Induced Neuroglial and Biochemical Changes. Neurotox Res. 2018 May; 33(4):738-48

22 Amin SN, El-Aidi AA, Ali MM, Attia YM, Rashed LA. Modification of hippocampal markers of synaptic plasticity by memantine in animal models of acute and repeated restraint stress: implications for memory and behavior. Neuromolecular Med. 2015 Jun; 17(2):121-36

23 Marvanová M, Lakso M, Pirhonen J, Nawa $\mathrm{H}$, Wong G, Castrén E. The neuroprotective agent memantine induces brain-derived neurotrophic factor and trkB receptor expression in rat brain. Mol Cell Neurosci. 2001 Sep; 18(3):247-58.

24 Ezoulin MJ, Ombetta JE, Dutertre-Catella H, Warnet JM, Massicot F. Antioxidative properties of galantamine on neuronal damage induced by hydrogen peroxide in SK-N-SH cells. Neurotoxicology. 2008 Mar;29(2):2707.

25 Melo JB, Sousa C, Garção P, Oliveira CR, Agostinho P. Galantamine protects against oxidative stress induced by amyloid-beta peptide in cortical neurons. Eur J Neurosci. 2009 Feb;29(3):455-64.

26 Tsvetkova D, Obreshkova D, Zheleva-Dimitrova D, Saso L. Antioxidant activity of galantamine and some of its derivatives. Curr Med Chem. 2013;20(36):4595-608.

27 Sozio P, Cerasa LS, Laserra S, Cacciatore I, Cornacchia C, Di Filippo ES, et al. Memantine-sulfur containing antioxidant conjugates as potential prodrugs to improve the treatment of Alzheimer's disease. Eur J Pharm Sci. 2013 May;49(2):187-98.

28 Yang Y, Paspalas CD, Jin LE, Picciotto MR, Arnsten AF, Wang M. Nicotinic $\alpha 7$ receptors enhance NMDA cognitive circuits in dorsolateral prefrontal cortex. Proc Natl Acad Sci USA. 2013 Jul;110(29):12078-83.

29 Sun Y, Yang Y, Galvin VC, Yang S, Arnsten AF, Wang M. Nicotinic $\alpha 4 \beta 2$ cholinergic receptor influences on dorsolateral prefrontal cortical neuronal firing during a working memory task. J Neurosci. 2017 May;37(21): 5366-77.
30 Nikiforuk A, Potasiewicz A, Kos T, Popik P. The combination of memantine and galantamine improves cognition in rats: the synergistic role of the $\alpha 7$ nicotinic acetylcholine and NMDA receptors. Behav Brain Res. 2016 Oct;313(313):214-8.

31 Woodruff-Pak DS, Tobia MJ, Jiao X, Beck $\mathrm{KD}$, Servatius RJ. Preclinical investigation of the functional effects of memantine and memantine combined with galantamine or donepezil. Neuropsychopharmacology. 2007 Jun;32(6):1284-94.

32 Lorrio S, Negredo P, Roda JM, García AG, López MG. Effects of memantine and galantamine given separately or in association, on memory and hippocampal neuronal loss after transient global cerebral ischemia in gerbils. Brain Res. 2009 Feb;1254:128-37.

33 Schneider JS, Pioli EY, Jianzhong Y, Li Q, Bezard E. Effects of memantine and galantamine on cognitive performance in aged rhesus macaques. Neurobiol Aging. 2013 Apr; 34(4):1126-32.

34 Reggiani AM, Simoni E, Caporaso R, Meunier J, Keller E, Maurice T, et al. In vivo characterization of ARN14140, a memantine/galantamine-based multi-target compound for Alzheimer's disease. Sci Rep. 2016 Sep;6(1): 33172.

35 Busquet P, Capurro V, Cavalli A, Piomelli D, Reggiani A, Bertorelli R. Synergistic effects of galantamine and memantine in attenuating scopolamine-induced amnesia in mice. J Pharmacol Sci. 2012;120(4):305-9.

36 Lopes JP, Tarozzo G, Reggiani A, Piomelli D, Cavalli A. Galantamine potentiates the neuroprotective effect of memantine against NMDA-induced excitotoxicity. Brain Behav. 2013 Mar;3(2):67-74.

37 Peters O, Lorenz D, Fesche A, Schmidtke K, Hüll M, Perneczky R, et al. A combination of galantamine and memantine modifies cognitive function in subjects with amnestic MCI. J Nutr Health Aging. 2012;16(6):544-8

38 Matsuzono K, Hishikawa N, Ohta Y, Yamashita T, Deguchi K, Nakano Y, et al. Combination Therapy of Cholinesterase Inhibitor (Donepezil or Galantamine) plus Memantine in the Okayama Memantine Study. J Alzheimers Dis. 2015;45(3):771-80.

39 Koola MM. Galantamine and memantine combination for cognition: enough or more than enough to translate from murines and macaques to men with schizophrenia? Asian J Psychiatr. Forthcoming 2017 Nov;S18762018(17)30465-3.

40 Koola MM, Parsaik AK. Galantamine-memantine combination effective in dementia: translate to dementia praecox? Schizophr Res Cogn. 2018 Jan;12:8-10.

41 Koola MM, Pillai A, Looney SW. Meta-Analysis of Randomized Controlled Trials of Galantamine in Schizophrenia. Significant Cognitive Enhancement. Under Review. 
42 Kishi T, Matsuda Y, Iwata N. Memantine add-on to antipsychotic treatment for residual negative and cognitive symptoms of schizophrenia: a meta-analysis. Psychopharmacology (Berl). 2017 Jul;234(14):2113-25.

43 Zheng W, Li XH, Yang XH, Cai DB, Ungvari GS, $\mathrm{Ng} \mathrm{CH}$, et al. Adjunctive memantine for schizophrenia: a meta-analysis of randomized, double-blind, placebo-controlled trials. Psychol Med. 2018 Jan;48(1):72-81.

44 Strassnig MT, Raykov T, O'Gorman C, Bowie CR, Sabbag S, Durand D, et al. Determinants of different aspects of everyday outcome in schizophrenia: the roles of negative symptoms, cognition, and functional capacity. Schizophr Res. 2015 Jun;165(1):76-82.

45 Ventura J, Subotnik KL, Gitlin MJ, GretchenDoorly D, Ered A, Villa KF, et al. Negative symptoms and functioning during the first year after a recent onset of schizophrenia and 8 years later. Schizophr Res. 2015 Feb;161(23):407-13.

46 Kirkpatrick B, Buchanan RW, McKenney PD, Alphs LD, Carpenter WT Jr. The Schedule for the Deficit syndrome: an instrument for research in schizophrenia. Psychiatry Res. 1989 Nov;30(2):119-23.

47 Jadad AR, Moore RA, Carroll D, Jenkinson C, Reynolds DJ, Gavaghan DJ, et al. Assessing the quality of reports of randomized clinical trials: is blinding necessary? Control Clin Trials. $1996 \mathrm{Feb} ; 17(1): 1-12$.

48 Berger VW, Alperson SY. A general framework for the evaluation of clinical trial quality. Rev Recent Clin Trials. 2009 May;4(2):79-88.

49 Keshavan MS, Lawler AN, Nasrallah HA, Tandon R. New drug developments in psychosis: Challenges, opportunities and strategies. Prog Neurobiol. 2017 May;152:3-20.

50 Collins FS, Tabak LA. Policy: NIH plans to enhance reproducibility. Nature. 2014 Jan; 505(7485):612-3.

51 Moher D, Avey M, Antes G, Altman DG. The National Institutes of Health and guidance for reporting preclinical research. BMC Med. 2015 Feb;13(1):34.

$52 \mathrm{Gu} \mathrm{J}$, Wu Y, Tang L. A controlled study of clozapine plus memantine in schizophrenia negative symptoms [In Chinese]. J Clin Psychiatry. 2012;22:261-3.

53 Rezaei F, Mohammad-Karimi M, Seddighi S, Modabbernia A, Ashrafi M, Salehi B, et al. Memantine add-on to risperidone for treatment of negative symptoms in patients with stable schizophrenia: randomized, doubleblind, placebo-controlled study. J Clin Psychopharmacol. 2013 Jun;33(3):336-42.

54 Omranifard V, Rajabi F, Mohammadian-Sichani M, Maracy M. The effect of add-on memantine on global function and quality of life in schizophrenia: A randomized, doubleblind, controlled, clinical trial. Adv Biomed Res. 2015 Sep;4:211.
55 Fakhri A, Pakseresht S, Haghdoost MR, Hekmatkhah N, Torkashvand M, Ghorbanzadeh B. Memantine Enhances the Effect of Olanzapine in Patients With Schizophrenia: A Randomized, Placebo-Controlled Study. Acta Med Iran. 2016 Nov;54(11):696-703.

56 Omranifard V, Rajabi F, Mohammadian-Sichani M, Maracy MR. The effect of add-on memantine on positive, negative and depressive symptoms of schizophrenia: a doubleblind, randomized, controlled trial. Actas Esp Psiquiatr. 2017 May;45(3):108-15.

57 Buchanan RW, Davis M, Goff D, Green MF, Keefe RS, Leon AC, et al. A summary of the FDA-NIMH-MATRICS workshop on clinical trial design for neurocognitive drugs for schizophrenia. Schizophr Bull. 2005 Jan; 31(1):5-19.

58 Buchanan RW, Keefe RS, Umbricht D, Green MF, Laughren T, Marder SR. The FDANIMH-MATRICS guidelines for clinical trial design of cognitive-enhancing drugs: what do we know 5 years later? Schizophr Bull. 2011 Nov;37(6):1209-17.

59 Schubert MH, Young KA, Hicks PB. Galantamine improves cognition in schizophrenic patients stabilized on risperidone. Biol Psychiatry. 2006 Sep;60(6):530-3.

60 Dyer MA, Freudenreich O, Culhane MA, Pachas GN, Deckersbach T, Murphy E, et al. High-dose galantamine augmentation inferior to placebo on attention, inhibitory control and working memory performance in nonsmokers with schizophrenia. Schizophr Res. 2008 Jul;102(1-3):88-95.

61 Lieberman JA, Papadakis K, Csernansky J, Litman R, Volavka J, Jia XD, et al.; MEMMD-29 Study Group. A randomized, placebo-controlled study of memantine as adjunctive treatment in patients with schizophrenia. Neuropsychopharmacology. 2009 Apr;34(5): 1322-9.

62 Buchanan RW, Kelly DL, Weiner E, Gold JM, Strauss GP, Koola MM, et al. A Randomized Clinical Trial of Oxytocin or Galantamine for the Treatment of Negative Symptoms and Cognitive Impairments in People With Schizophrenia. J Clin Psychopharmacol. 2017 Aug;37(4):394-400.

63 Keefe RS, Buchanan RW, Marder SR, Schooler NR, Dugar A, Zivkov M, et al. Clinical trials of potential cognitive-enhancing drugs in schizophrenia: what have we learned so far? Schizophr Bull. 2013 Mar;39(2):417-35.

64 Husa AP, Moilanen J, Murray GK, Marttila R, Haapea M, Rannikko I, et al. Lifetime antipsychotic medication and cognitive performance in schizophrenia at age 43 years in a general population birth cohort. Psychiatry Res. 2017 Jan;247:130-8.

65 Suzuki T, Remington G, Mulsant BH, Rajji TK, Uchida H, Graff-Guerrero A, et al. Treatment resistant schizophrenia and response to antipsychotics: a review. Schizophr Res. 2011 Dec;133(1-3):54-62.
66 Frydecka D, Beszłej JA, Gościmski P, Kiejna A, Misiak B. Profiling cognitive impairment in treatment-resistant schizophrenia patients. Psychiatry Res. 2016 Jan;235:133-8.

67 Chew ML, Mulsant BH, Pollock BG, Lehman ME, Greenspan A, Mahmoud RA, et al. Anticholinergic activity of 107 medications commonly used by older adults. J Am Geriatr Soc. 2008 Jul;56(7):1333-41.

68 Mazinani R, Nejati S, Khodaei M. Effects of memantine added to risperidone on the symptoms of schizophrenia: A randomized double-blind, placebo-controlled clinical trial. Psychiatry Res. 2017 Jan;247(247):291-5.

69 Frith CD, Stevens M, Johnstone EC, Deakin JF, Lawler P, Crow TJ. Effects of ECT and depression on various aspects of memory. $\mathrm{Br} \mathrm{J}$ Psychiatry. 1983 Jun;142(6):610-7.

70 Lindenmayer JP, Khan A. Galantamine augmentation of long-acting injectable risperidone for cognitive impairments in chronic schizophrenia. Schizophr Res. 2011 Feb; 125(2-3):267-77.

71 Koola MM, Gorelick DA, McMahon RP, Liu F, Huestis MA, Linthicum J, et al. Psychiatric symptom differences in people with schizophrenia associated with substantial lifetime substance use but no current substance use disorder. Schizophr Res. 2014 Jan;152(1): 315-6.

72 Deutsch SI, Schwartz BL, Schooler NR, Brown $\mathrm{CH}$, Rosse RB, Rosse SM. Targeting alpha-7 nicotinic neurotransmission in schizophrenia: a novel agonist strategy. Schizophr Res. 2013 Aug; 148(1-3):138-44.

73 Green MF, Nuechterlein KH, Gold JM, Barch DM, Cohen J, Essock S, et al. Approaching a consensus cognitive battery for clinical trials in schizophrenia: the NIMH-MATRICS conference to select cognitive domains and test criteria. Biol Psychiatry. 2004 Sep;56(5):3017.

74 Bhakta SG, Chou HH, Rana B, Talledo JA, Balvaneda B, Gaddis L, et al. Effects of acute memantine administration on MATRICS Consensus Cognitive Battery performance in psychosis: testing an experimental medicine strategy. Psychopharmacology (Berl). 2016 Jun;233(12):2399-410.

75 Swerdlow NR, Bhakta S, Chou HH, Talledo JA, Balvaneda B, Light GA. Memantine effects on sensorimotor gating and mismatch negativity in patients with chronic psychosis. Neuropsychopharmacology. 2016 Jan;41(2):419-30.

76 Light GA, Zhang W, Joshi YB, Bhakta S, Talledo JA, Swerdlow NR. Single-dose memantine improves cortical oscillatory response dynamics in patients with schizophrenia. Neuropsychopharmacology. $2017 \quad$ Dec: 42(13):2633-9.

77 Overall JE, Gorham DR. The brief psychiatric rating scale. Psychol Rep. 1962;10(3):799812
Antipsychotic-Galantamine-Memantine Combination for Schizophrenia Treatment
Mol Neuropsychiatry 2018;4:134-148 DOI: $10.1159 / 000494495$ 
78 Kay SR, Fiszbein A, Opler LA. The positive and negative syndrome scale (PANSS) for schizophrenia. Schizophr Bull. 1987;13(2): 261-76.

79 Reid MA, Stoeckel LE, White DM, Avsar KB, Bolding MS, Akella NS, et al. Assessments of function and biochemistry of the anterior cingulate cortex in schizophrenia. Biol Psychiatry. 2010 Oct;68(7):625-33.

80 Keefe RS, Meltzer HA, Dgetluck N, Gawryl M, Koenig G, Moebius HJ, et al. Randomized, Double-Blind, Placebo-Controlled Study of Encenicline, an a7 Nicotinic Acetylcholine Receptor Agonist, as a Treatment for Cognitive Impairment in Schizophrenia. Neuropsychopharmacology. 2015 Dec;40(13):3053-60.

81 Patterson TL, Goldman S, McKibbin CL, Hughs T, Jeste DV. UCSD PerformanceBased Skills Assessment: development of a new measure of everyday functioning for severely mentally ill adults. Schizophr Bull. 2001;27(2):235-45.

82 Addington $\mathrm{D}$, Addington J, Maticka-Tyndale E, Joyce J. Reliability and validity of a depression rating scale for schizophrenics. Schizophr Res. 1992 Mar;6(3):201-8.

83 Wijegunaratne $\mathrm{H}$, Qazi $\mathrm{H}$, Koola MM Chronic and bedtime use of benztropine with antipsychotics: is it necessary? Schizophr Res. 2014 Mar;153(1-3):248-9.

84 Eum S, Hill SK, Rubin LH, Carnahan RM, Reilly JL, Ivleva EI, et al. Cognitive burden of anticholinergic medications in psychotic disorders. Schizophr Res. 2017 Dec;190:129-35.

85 Lee JG, Lee SW, Lee BJ, Park SW, Kim GM, Kim YH. Adjunctive memantine therapy for cognitive impairment in chronic schizophrenia: a placebo-controlled pilot study. Psychiatry Investig. 2012 Jun;9(2):166-73.

86 Lee SW, Lee JG, Lee BJ, Kim YH. A 12-week, double-blind, placebo-controlled trial of galantamine adjunctive treatment to conventional antipsychotics for the cognitive impairments in chronic schizophrenia. Int Clin Psychopharmacol. 2007 Mar;22(2):63-8.

87 de Lucena D, Fernandes BS, Berk M, Dodd S, Medeiros DW, Pedrini M, et al. Improvement of negative and positive symptoms in treatment-refractory schizophrenia: a doubleblind, randomized, placebo-controlled trial with memantine as add-on therapy to clozapine. J Clin Psychiatry. 2009 Oct;70(10): 1416-23.

88 Veerman SR, Schulte PF, Smith JD, de Haan L. Memantine augmentation in clozapinerefractory schizophrenia: a randomized, double-blind, placebo-controlled crossover study. Psychol Med. 2016 Jul;46(9):1909-21.

89 Buchanan RW, Conley RR, Dickinson D, Ball MP, Feldman S, Gold JM, et al. Galantamine for the treatment of cognitive impairments in people with schizophrenia. Am J Psychiatry. 2008 Jan;165(1):82-9.

90 Shiovitz TM, Bain EE, McCann DJ, Skolnick $\mathrm{P}$, Laughren T, Hanina A, et al. Mitigating the effects of nonadherence in clinical trials. $J$ Clin Pharmacol. 2016 Sep;56(9):1151-64.
91 Kirkpatrick B, Fenton WS, Carpenter WT Jr, Marder SR. The NIMH-MATRICS consensus statement on negative symptoms. Schizophr Bull. 2006 Apr;32(2):214-9.

92 Perkins MN, Stone TW. An iontophoretic investigation of the actions of convulsant kynurenines and their interaction with the endogenous excitant quinolinic acid. Brain Res. 1982 Sep;247(1):184-7.

93 Ganong AH, Lanthorn TH, Cotman CW. Kynurenic acid inhibits synaptic and acidic amino acid-induced responses in the rat hippocampus and spinal cord. Brain Res. 1983 Aug;273(1):170-4.

94 Hilmas C, Pereira EF, Alkondon M, Rassoulpour A, Schwarcz R, Albuquerque EX. The brain metabolite kynurenic acid inhibits alpha7 nicotinic receptor activity and increases non-alpha7 nicotinic receptor expression: physiopathological implications. J Neurosci. 2001 Oct;21(19):7463-73.

95 Erhardt S, Schwieler L, Imbeault S, Engberg G. The kynurenine pathway in schizophrenia and bipolar disorder. Neuropharmacology. 2017 Jan;112 Pt B:297-306.

96 Plitman E, Iwata Y, Caravaggio F, Nakajima S, Chung JK, Gerretsen P, et al. Kynurenic acid in schizophrenia: a systematic review and meta-analysis. Schizophr Bull. 2017 Jul; 43(4):764-77.

97 Wonodi I, Schwarcz R. Cortical kynurenine pathway metabolism: a novel target for cognitive enhancement in Schizophrenia. Schizophr Bull. 2010 Mar;36(2):211-8.

98 Erhardt S, Schwieler L, Nilsson L, Linderholm K, Engberg G. The kynurenic acid hypothesis of schizophrenia. Physiol Behav. 2007 Sep;92(1-2):203-9.

99 Flis M, Szymona K, Morylowska-Topolska J, Urbańska A, Krukow P, Kandefer-Szerszeń $\mathrm{M}$, et al. [The kynurenic acid hypothesis - a new look at etiopathogenesis and treatment of schizophrenia]. Pol Merkur Lekarski. 2016 Sep;41(243):160-4.

100 Koola MM, Buchanan RW, Pillai A, Aitchison KJ, Weinberger DR, Aaronson ST, et al. Potential role of the combination of galantamine and memantine to improve cognition in schizophrenia. Schizophr Res. 2014 Aug;157(1-3):84-9.

101 Koola MM. Kynurenine pathway and cognitive impairments in schizophrenia: pharmacogenetics of galantamine and memantine. Schizophr Res Cogn. 2016 Jun;4:4-9.

102 Koola MM, Sklar J, Davis W, Nikiforuk A, Meissen JK, Sawant-Basak A, et al. Kynurenine pathway in schizophrenia: galantaminememantine combination for cognitive impairments. Schizophr Res. 2018 Mar;193: 459-60.

103 Atlas A, Gisslén M, Nordin C, Lindström L, Schwieler L. Acute psychotic symptoms in HIV-1 infected patients are associated with increased levels of kynurenic acid in cerebrospinal fluid. Brain Behav Immun. 2007 Jan;21(1):86-91.
104 Olsson SK, Sellgren C, Engberg G, Landén M, Erhardt S. Cerebrospinal fluid kynurenic acid is associated with manic and psychotic features in patients with bipolar I disorder. Bipolar Disord. 2012 Nov; 14(7):71926.

105 Navrotskaya V, Wnorowski A, Turski W, Oxenkrug G. Effect of Kynurenic Acid on Pupae Viability of Drosophila melanogaster cinnabar and cardinal Eye Color Mutants with Altered Tryptophan-Kynurenine Metabolism. Neurotox Res. 2018 Aug;34(2): 324-31.

106 Linderholm KR, Alm MT, Larsson MK, Olsson SK, Goiny M, Hajos M, et al. Inhibition of kynurenine aminotransferase II reduces activity of midbrain dopamine neurons. Neuropharmacology. 2016 Mar; 102: $42-7$.

107 Karakuła-Juchnowicz H, Flis M, Szymona K, Kuczyńska M, Stelmach E, Kowal-Popczak A. [New prospects for antipsychotic treatment - the role of the kynurenine pathway]. Psychiatr Pol. 2014 Nov-Dec;48(6): 1167-77.

108 Bali ZK, Nagy LV, Hernádi I. Alpha7 Nicotinic Acetylcholine Receptors Play a Predominant Role in the Cholinergic Potentiation of N-Methyl-D-Aspartate Evoked Firing Responses of Hippocampal CA1 Pyramidal Cells. Front Cell Neurosci. 2017 Sep;11:271.

109 Flores-Barrera E, Thomases DR, Cass DK, Bhandari A, Schwarcz R, Bruno JP, et al. Preferential Disruption of Prefrontal GABAergic Function by Nanomolar Concentrations of the $a 7 \mathrm{nACh}$ Negative Modulator Kynurenic Acid. J Neurosci. 2017 Aug; 37(33):7921-9.

110 Townsend M, Whyment A, Walczak JS, Jeggo R, van den Top M, Flood DG, et al. a7$n A C h R$ agonist enhances neural plasticity in the hippocampus via a GABAergic circuit. Neurophysiol. 2016 Dec;116(6):2663-75.

111 Beggiato S, Tanganelli S, Fuxe K, Antonelli T, Schwarcz R, Ferraro L. Endogenous kynurenic acid regulates extracellular GABA levels in the rat prefrontal cortex. Neuropharmacology. 2014 Jul;82:11-8.

112 Balla A, Nattini ME, Sershen H, Lajtha A, Dunlop DS, Javitt DC. GABAB/NMDA receptor interaction in the regulation of extracellular dopamine levels in rodent prefrontal cortex and striatum. Neuropharmacology. 2009 Apr;56(5):915-21.

113 Alkondon M, Albuquerque EX. Nicotinic acetylcholine receptor alpha7 and alpha4beta2 subtypes differentially control GABAergic input to CA1 neurons in rat hippocampus. J Neurophysiol. 2001 Dec;86(6):304355.

114 Buhler AV, Dunwiddie TV. alpha7 nicotinic acetylcholine receptors on GABAergic interneurons evoke dendritic and somatic inhibition of hippocampal neurons. J Neurophysiol. 2002 Jan;87(1):548-57. 
115 Oka M, Nakaaki S, Negi A, Miyata J, Nakagawa A, Hirono N, et al. Predicting the neural effect of switching from donepezil to galantamine based on single-photon emission computed tomography findings in patients with Alzheimer's disease. Psychogeriatrics. 2016 Mar; 16(2):121-34.

116 Freedman R, Olincy A, Buchanan RW, Harris JG, Gold JM, Johnson L, et al. Initial phase 2 trial of a nicotinic agonist in schizophrenia. Am J Psychiatry. 2008 Aug;165(8): 1040-7.

117 Kertesz A, Morlog D, Light M, Blair M, Davidson W, Jesso S, et al. Galantamine in frontotemporal dementia and primary progressive aphasia. Dement Geriatr Cogn Disord. 2008;25(2):178-85.

118 Hong JM, Shin DH, Lim TS, Lee JS, Huh K. Galantamine administration in chronic post-stroke aphasia. J Neurol Neurosurg Psychiatry. 2012 Jul;83(7):675-80.

119 Lieberman JA, Dunbar G, Segreti AC, Girgis $\mathrm{RR}$, Seoane F, Beaver JS, et al. A randomized exploratory trial of an a-7 nicotinic receptor agonist (TC-5619) for cognitive enhancement in schizophrenia. Neuropsychopharmacology. 2013 May;38(6):968-75.

120 Umbricht D, Keefe RS, Murray S, Lowe DA, Porter R, Garibaldi G, et al. A randomized, placebo-controlled study investigating the nicotinic $\alpha 7$ agonist, RG3487, for cognitive deficits in schizophrenia. Neuropsychopharmacology. 2014 Jun;39(7):1568-77.

121 Réus GZ, Abelaira HM, Stringari RB, Fries GR, Kapczinski F, Quevedo J. Memantine treatment reverses anhedonia, normalizes corticosterone levels and increases BDNF levels in the prefrontal cortex induced by chronic mild stress in rats. Metab Brain Dis. 2012 Jun;27(2):175-82.

122 Uribe E, Sánchez-Mendoza E, Nieves N, Merchor G. Neonatal Administration of Memantine Enhances Social Cognition in Adult Rats Subjected to Early Maternal Deprivation. Exp Neurobiol. 2016 Dec;25(6): 328-32.

123 Barbancho MA, Berthier ML, Navas-Sánchez P, Dávila G, Green-Heredia C, GarcíaAlberca JM, et al. Bilateral brain reorganization with memantine and constraint-induced aphasia therapy in chronic post-stroke aphasia: an ERP study. Brain Lang. 2015 Jun-Jul;145-146:1-10.

124 Paraschakis A. Tackling negative symptoms of schizophrenia with memantine. Case Rep Psychiatry. 2014;2014:384783.

125 Kanchanatawan B, Sirivichayakul S, Ruxrungtham K, Carvalho AF, Geffard M, Ormstad $\mathrm{H}$, et al. Deficit, but not nondeficit, schizophrenia is characterized by mucosaassociated activation of the tryptophan catabolite (TRYCAT) pathway with highly specific increases in IgA responses directed to picolinic, xanthurenic, and quinolinic acid. Mol Neurobiol. 2018 Feb;55(2):152436.

Antipsychotic-Galantamine-Memantine Combination for Schizophrenia Treatment
126 Buchanan RW, Javitt DC, Marder SR, Schooler NR, Gold JM, McMahon RP, et al. The Cognitive and Negative Symptoms in Schizophrenia Trial (CONSIST): the efficacy of glutamatergic agents for negative symptoms and cognitive impairments. Am J Psychiatry. 2007 Oct;164(10):1593-602.

127 Arango C, Garibaldi G, Marder SR. Pharmacological approaches to treating negative symptoms: a review of clinical trials. Schizophr Res. 2013 Nov;150(2-3):346-52.

128 Kantrowitz JT. Managing Negative Symptoms of Schizophrenia: How Far Have We Come? CNS Drugs. 2017 May;31(5):373-88.

129 Galderisi S, Merlotti E, Mucci A. Neurobiological background of negative symptoms. Eur Arch Psychiatry Clin Neurosci. 2015 Oct;265(7):543-58.

130 Rosburg T, Kreitschmann-Andermahr I. The effects of ketamine on the mismatch negativity (MMN) in humans - A metaanalysis. Clin Neurophysiol. 2016 Feb; 127(2):1387-94.

131 Javitt DC, Steinschneider M, Schroeder CE, Arezzo JC. Role of cortical N-methyl-D-aspartate receptors in auditory sensory memory and mismatch negativity generation: implications for schizophrenia. Proc Natl Acad Sci USA. 1996 Oct;93(21):11962-7.

132 Baldeweg T, Wong D, Stephan KE. Nicotinic modulation of human auditory sensory memory: evidence from mismatch negativity potentials. Int J Psychophysiol. 2006 Jan; 59(1):49-58.

133 Martin LF, Davalos DB, Kisley MA. Nicotine enhances automatic temporal processing as measured by the mismatch negativity waveform. Nicotine Tob Res. 2009 Jun;11(6): 698-706.

134 Dulude L, Labelle A, Knott VJ. Acute nicotine alteration of sensory memory impairment in smokers with schizophrenia. J Clin Psychopharmacol. 2010 Oct;30(5):541-8.

135 Rowland LM, Summerfelt A, Wijtenburg SA, Du X, Chiappelli JJ, Krishna N, et al. Frontal Glutamate and $\gamma$-Aminobutyric Acid Levels and Their Associations With Mismatch Negativity and Digit Sequencing Task Performance in Schizophrenia. JAMA Psychiatry. 2016 Feb;73(2):166-74.

136 Javitt DC, Freedman R. Sensory processing dysfunction in the personal experience and neuronal machinery of schizophrenia. Am J Psychiatry. 2015 Jan;172(1):17-31.

137 Kantrowitz JT, Hoptman MJ, Leitman DI, Moreno-Ortega M, Lehrfeld JM, Dias E, et al. Neural substrates of auditory emotion recognition deficits in schizophrenia. J Neurosci. 2015 Nov;35(44):14909-21.

138 Thomas ML, Green MF, Hellemann G, Sugar CA, Tarasenko M, Calkins ME, et al. Modeling deficits from early auditory information processing to psychosocial functioning in schizophrenia. JAMA Psychiatry. 2017 Jan;74(1):37-46.
139 Biagianti B, Roach BJ, Fisher M, Loewy R, Ford JM, Vinogradov S, et al. Trait aspects of auditory mismatch negativity predict response to auditory training in individuals with early illness schizophrenia. Neuropsychiatr Electrophysiol. 2017;3(1):2.

140 Perez VB, Tarasenko M, Miyakoshi M, Pianka ST, Makeig SD, Braff DL, et al. Mismatch negativity is a sensitive and predictive biomarker of perceptual learning during auditory cognitive training in schizophrenia. Neuropsychopharmacology. 2017 Oct; 42(11):2206-13.

141 Korostenskaja M, Nikulin VV, Kicić D, Nikulina AV, Kähkönen S. Effects of NMDA receptor antagonist memantine on mismatch negativity. Brain Res Bull. 2007 May; 72(4-6):275-83.

142 Tikhonravov D, Neuvonen T, Pertovaara A, Savioja K, Ruusuvirta T, Näätänen R, et al. Dose-related effects of memantine on a mismatch negativity-like response in anesthetized rats. Neuroscience. 2010 Jun;167(4): 1175-82.

143 Preskorn SH, Gawryl M, Dgetluck N, Palfreyman M, Bauer LO, Hilt DC. Normalizing effects of EVP-6124, an a-7 nicotinic partial agonist, on event-related potentials and cognition: a proof of concept, randomized trial in patients with schizophrenia. J Psychiatr Pract. 2014 Jan;20(1):12-24.

144 Knott V, Shah D, Millar A, McIntosh J, Fisher D, Blais C, et al. Nicotine, Auditory Sensory Memory, and sustained Attention in a Human Ketamine Model of Schizophrenia: Moderating Influence of a Hallucinatory Trait. Front Pharmacol. 2012 Sep;3:172.

145 Hamilton HK, D'Souza DC, Ford JM, Roach $\mathrm{BJ}$, Kort NS, Ahn $\mathrm{KH}$, et al. Interactive effects of an $\mathrm{N}$-methyl-d-aspartate receptor antagonist and a nicotinic acetylcholine receptor agonist on mismatch negativity: implications for schizophrenia. Schizophr Res. 2018 Jan;191:87-94.

146 Kantrowitz JT. N-methyl-d-aspartate-type glutamate receptor modulators and related medications for the enhancement of auditory system plasticity in schizophrenia. Schizophr Res. Forthcoming 2018 Feb; S0920-9964(18)30051-3.

147 Thiebes S, Leicht G, Curic S, Steinmann S, Polomac N, Andreou C, et al. Glutamatergic deficit and schizophrenia-like negative symptoms: new evidence from ketamine-induced mismatch negativity alterations in healthy male humans. J Psychiatry Neurosci. 2017 Jun;42(4):273-83.

148 Bailey SJ, Neill JC, Moran PM. Pharmacology of cognition: a panacea for neuropsychiatric disease? Br J Pharmacol. 2017 Oct; 174(19):3133-5.

149 Heaton RK, Baade LE, Johnson KL. Neuropsychological test results associated with psychiatric disorders in adults. Psychol Bull. 1978 Jan;85(1):141-62. 
150 Koola MM: Galantamine and memantine combination for cognitive impairments due to electroconvulsive therapy, traumatic brain injury and neurologic and psychiatric disorders: kynurenic acid and mismatch negativity target engagement. Prim Care Companion CNS Disord. 2018 Mar;20(2): $1-8$.

151 Koola MM. Attenuated mismatch negativity in attenuated psychosis syndrome predicts psychosis: can galantamine-memantine combination prevent psychosis? Mol Neuropsychiatry. 2018;4(2):71-4.

152 Kantrowitz JT, Javitt DC. N-methyl-d-aspartate (NMDA) receptor dysfunction or dysregulation: the final common pathway on the road to schizophrenia? Brain Res Bull. 2010 Sep;83(3-4):108-21.

153 Kucinski AJ, Stachowiak MK, Wersinger SR, Lippiello PM, Bencherif M. Alpha7 neuronal nicotinic receptors as targets for novel therapies to treat multiple domains of schizophrenia. Curr Pharm Biotechnol. 2011 Mar; 12(3):437-48.

154 Kohlhaas KL, Bitner RS, Gopalakrishnan M, Rueter LE. Effects of $\alpha 7$ nicotinic acetylcholine receptor agonists on antipsychotic efficacy in a preclinical mouse model of psychosis. Psychopharmacology (Berl). 2012 Apr; 220(4):823-33.

155 Nikiforuk A, Kos T, Hołuj M, Potasiewicz A, Popik P. Positive allosteric modulators of alpha 7 nicotinic acetylcholine receptors reverse ketamine-induced schizophrenia-like deficits in rats. Neuropharmacology. 2016 Feb;101:389-400.
156 Potasiewicz A, Hołuj M, Kos T, Popik P, Arias HR, Nikiforuk A. 3-Furan-2-yl-N-ptolyl-acrylamide, a positive allosteric modulator of the $\alpha 7$ nicotinic receptor, reverses schizophrenia-like cognitive and social deficits in rats. Neuropharmacology. 2017 Feb; 113 Pt A:188-97.

157 Lewis AS, Olincy A, Buchanan RW, Kem WR, Picciotto MR, Freedman R. Effects of a nicotinic agonist on the Brief Psychiatric Rating Scale five-factor subscale model in schizophrenia. Schizophr Res. 2018 May; 195:568-9.

158 Massey KA, Zago WM, Berg DK. BDNF upregulates alpha7 nicotinic acetylcholine receptor levels on subpopulations of hippocampal interneurons. Mol Cell Neurosci. 2006;33(4):381-8.

159 Navakkode S, Korte M. Cooperation between cholinergic and glutamatergic receptors are essential to induce BDNF-dependent long-lasting memory storage. Hippocampus. 2012;22(2):335-46.

160 Penadés R, García-Rizo C, Bioque M, González-Rodríguez A, Cabrera B, Mezquida G, Bernardo M. The search for new biomarkers for cognition in schizophrenia. Schizophr Res Cogn. 2015;2(4):172-178.
161 Ramsay RR, Popovic-Nikolic MR, Nikolic K, Uliassi E, Bolognesi ML. A perspective on multi-target drug discovery and design for complex diseases. Clin Transl Med. 2018 Jan;7(1):3.

162 Kondej M, Stępnicki P, Kaczor AA. MultiTarget Approach for Drug Discovery against Schizophrenia. Int J Mol Sci. 2018;19(10):130.

163 Grossberg GT, Manes F, Allegri RF, Gutiérrez-Robledo LM, Gloger S, Xie L, et al. The safety, tolerability, and efficacy of once-daily memantine $(28 \mathrm{mg})$ : a multinational, randomized, double-blind, placebo-controlled trial in patients with moderate-to-severe Alzheimer's disease taking cholinesterase inhibitors. CNS Drugs. 2013 Jun;27(6):469-78.

164 Steullet P, Cabungcal JH, Monin A, Dwir D, O'Donnell P, Cuenod M, et al. Redox dysregulation, neuroinflammation, and NMDA receptor hypofunction: A "central hub" in schizophrenia pathophysiology? Schizophr Res. 2016 Sep;176(1):41-51.

165 Kraepelin E. Dementia Praecox and Paraphrenia. Edinburgh: E\&S Livingstone; 1919.

166 Carpenter WT Jr. Clinical constructs and therapeutic discovery. Schizophr Res. 2004 Dec;72(1):69-73.

167 Lachin JM. Statistical considerations in the intent-to-treat principle. Control Clin Trials. 2000 Jun;21(3):167-89.

168 Veerman SR, Schulte PF, Deijen JB, de Haan L. Adjunctive memantine in clozapinetreated refractory schizophrenia: an openlabel 1-year extension study. Psychol Med. 2017 Jan;47(2):363-75. 